\title{
TARGET PENCAPAIAN RENCANA UMUM KESELAMATAN JALAN (RUNK JALAN) DI PROVINSI JAWA TIMUR PADA TAHUN 2012
}

\author{
Budi Hartanto Susilo \\ Dosen Tetap, Jurusan Teknik Sipil, Fakultas Teknik, Universitas Kristen Maranatha \\ budiharsus@yahoo.com
}

\begin{abstract}
ABSTRAK
Jawa Timur merupakan provinsi tertinggi dalam jumlah korban meninggal dunia (4575 jiwa) akibat kecelakaan lalulintas dalam tahun 2010. Dalam tahun 2011 ternyata jumlah kecelakaan meningkat, mengapa? Rupanya target RUNK jalan (Rencana Umum Nasional Keselamatan) belum tercapai karena belum diterapkan. Mungkin hal ini disebabkan oleh karena belum adanya sosialisasi yang efektif tentang RUNK sehingga pihak pengatur belum menerapkan RUNK secara terkoordinir dan selaras, dan pengguna jalan masih kurang sadar bahayanya kecelakaan dijalan dan belum waspada dalam berlalu lintas. Berdasarkan analisis data yang terkumpul dalam pelatihan cara menghitung target RUNK, dengan menggunakan lima parameter analisis, yaitu jumlah kejadian kecelakaan, tingkat kecelakaan, tingkat fatalitas (CFR), indeks fatalitas per kendaraan bermotor dan indeks fatalitas per populasi, ternyata beberapa kota dan kabupaten mempunyai data jumlah korban fatal yang tinggi, diatas nilai rata-rata RUNK dan secara umum kondisi kecelakaan lalulintas tahun 2011 lebih jelek dari kondisi tahun 2010.
\end{abstract}

Kata kunci: RUNK, Jawa Timur, jumlah kecelakaan, tingkat kecelakaan, indeks fatalitas.

\begin{abstract}
East Java is a province in the highest number of deaths (4575 people) due to traffic accidents in 2010. In 2011 turned out to be the number of accidents increased, why? Apparently the target RUNK Jalan (Road Safety National Plan) has not been achieved because it has not applied. Perhaps this is caused by the absence of effective socialization of RUNK so that the regulator has not been implemented RUNK in a coordinated and aligned, and road users are less aware of the dangers of an accident on the street and not alert in traffic. Based on the data collected in the training of how to calculate the target of RUNK, using the parameters analysis (the number of accidents, the rate of accidents, the case fatality rate, and index of fatalities), it appeared that some cities have data a high number of fatal victims, above average of RUNK.
\end{abstract}

Keywords: RUNK, East Java, number of accidents, rate of accidents, index of fatalities.

\section{PENDAHULUAN}

Dokumen Rencana Umum Nasional Keselamatan (RUNK) Jalan disusun berdasarkan amanat Pasal 203 Undang-Undang Nomor 22 Tahun 2009, sebagai wujud tanggung jawab Pemerintah dalam menjamin keselamatan lalu lintas jalan. RUNK Jalan tersebut bertujuan untuk memberikan pedoman bagi para pemangku kebijakan agar dapat merencanakan dan melaksanakan penanganan keselamatan jalan secara terkoordinir dan selaras.

Target Pencapaian Rencana Umum Keselamatan Jalan (Runk Jalan) di Provinsi Jawa Timur 
Dengan telah disusunnya RUNK Jalan tersebut, perlu dilakukan sosialisasi secara menyeluruh ke berbagai provinsi di Indonesia, selanjutnya dilakukan monitoring, evaluasi, dan analisis. Dalam makalah ini, akan dilakukan analisis data terkait kecelakaan yang terjadi di Provinsi Jawa Timur, sehingga dari situ terlihat bagaimana penanganan/pencegahan terhadap kecelakaan yang ada di Jawa Timur. Apabila disinkronisasikan dengan target RUNK (Tabel 1), apakah lebih baik atau lebih buruk?

Tabel 1. Target RUNK Tahun 2011-2035

\begin{tabular}{|c|c|c|}
\hline Periode & Target & $\begin{array}{c}\text { Indeks fatalitas per } 10.000 \\
\text { kendaraan }\end{array}$ \\
\hline 2010 (baseline) & $0 \%$ & 3.93 \\
\hline $2011-2015$ & $20 \%$ & 3.14 \\
\hline $2016-2020$ & $50 \%$ & 1.96 \\
\hline $2021-2025$ & $65 \%$ & 1.37 \\
\hline $2026-2030$ & $75 \%$ & 0.98 \\
\hline $2031-2035$ & $80 \%$ & 0.79 \\
\hline
\end{tabular}

Sumber: RUNK, 2011

\section{IDENTIFIKASI MASALAH}

Pada tahun 2010, Jawa Timur menduduki posisi ke-1 di Indonesia dengan jumlah kecelakaan tertinggi, yaitu dengan jumlah korban meninggal dunia sebesar 4.575 jiwa (Gambar 1).

KORBAN MENINGGAL, KECELAKAAN LALU LINTAS TH 2010, 31.234 JIWA

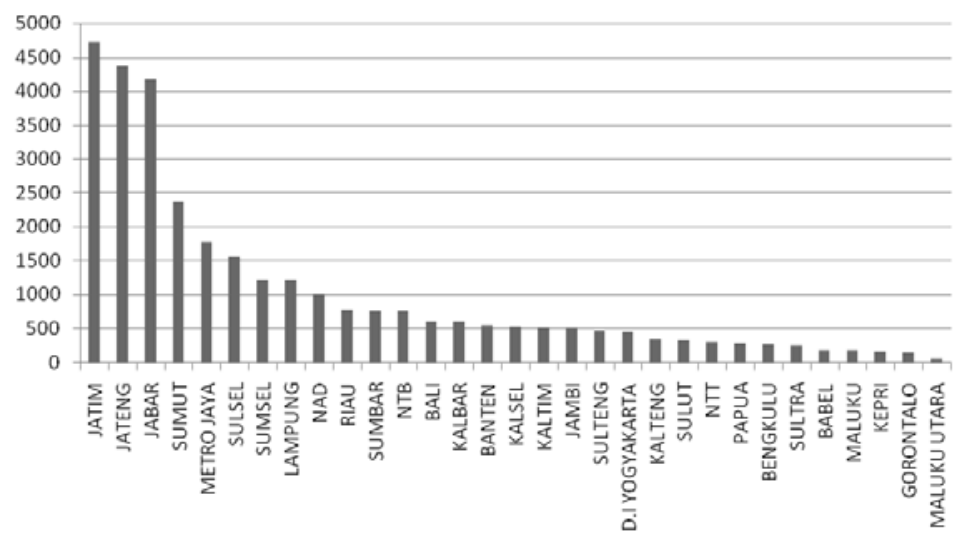

Gambar 1. Jumlah Korban Meninggal Dunia Akibat Kecelakaan Lalu Lintas Tahun 2010, KORLANTAS POLRI (2011) 
Berdasarkan data yang diperoleh dari Dinas Perhubungan tiap-tiap kab/kota di Jawa Timur, data kecelakaan tahun 2010 dan 2011 di Jawa Timur menurut kab/kota ditunjukkan oleh Tabel 2a dan Tabel 2b.

Tabel 2a. Data Kecelakaan Tahun 2010

\begin{tabular}{|l|c|r|r|r|}
\hline \multicolumn{1}{|c|}{ Kota / Kab } & $\begin{array}{c}\text { Jumlah } \\
\text { Kecelakaan }\end{array}$ & $\begin{array}{c}\text { Jumlah } \\
\text { Korban MD }\end{array}$ & $\begin{array}{c}\text { Jumlah } \\
\text { Ranmor }\end{array}$ & $\begin{array}{c}\text { Jumlah } \\
\text { Populasi }\end{array}$ \\
\hline Kota Blitar & 148 & 30 & 76209 & 100000 \\
\hline Kab. Jember & 336 & 55 & 187723 & 1008458 \\
\hline Kab. Jombang & 291 & 178 & 256728 & 1202407 \\
\hline Kab. Blitar & 290 & 25 & 104800 & 960000 \\
\hline Kab. Lumajang & 336 & 55 & 187723 & 1006458 \\
\hline Kab. Ngawi & 266 & 81 & 181680 & 893431 \\
\hline Kab. Sampang & 102 & 81 & 36590 & 870365 \\
\hline Kab. Magetan & 148 & 27 & 182250 & 693346 \\
\hline Kab. Malang & 101 & 48 & 437867 & 2447051 \\
\hline Kab. Pasuruan & 665 & 352 & 70400 & 4600000 \\
\hline Kab.Trenggalek & 151 & 22 & 152419 & 987000 \\
\hline Kab. Kediri & 482 & 103 & 315755 & 1485815 \\
\hline Kota Batu & 151 & 29 & 52800 & 210763 \\
\hline Kab. Mojokerto & 215 & 122 & 80600 & 1100480 \\
\hline Kota Probolinggo & 107 & 11 & 163200 & 217812 \\
\hline Kab. Sidoarjo & 171 & 148 & 188000 & 1941497 \\
\hline Kab. Tulung Agung & 681 & 62 & 381412 & 1037309 \\
\hline
\end{tabular}

Tabel 2b. Data Kecelakaan Tahun 2011

\begin{tabular}{|l|c|c|c|c|}
\hline \multicolumn{1}{|c|}{ Kota / Kab } & $\begin{array}{c}\text { Jumlah } \\
\text { Kecelakaan }\end{array}$ & $\begin{array}{c}\text { Jumlah } \\
\text { Korban MD }\end{array}$ & $\begin{array}{c}\text { Jumlah } \\
\text { Ranmor }\end{array}$ & $\begin{array}{c}\text { Jumlah } \\
\text { Populasi }\end{array}$ \\
\hline Kota Blitar & 152 & 23 & 65977 & 110000 \\
\hline Kab. Jember & 402 & 126 & 198165 & 1029103 \\
\hline Kab. Jombang & 567 & 180 & 272350 & 1215199 \\
\hline Kab. Blitar & 532 & 39 & 188600 & 980000 \\
\hline
\end{tabular}

Target Pencapaian Rencana Umum Keselamatan Jalan (Runk Jalan) di Provinsi Jawa Timur 


\begin{tabular}{|l|c|c|c|c|}
\hline \multicolumn{1}{|c|}{ Kota / Kab } & $\begin{array}{c}\text { Jumlah } \\
\text { Kecelakaan }\end{array}$ & $\begin{array}{c}\text { Jumlah } \\
\text { Korban MD }\end{array}$ & $\begin{array}{c}\text { Jumlah } \\
\text { Ranmor }\end{array}$ & $\begin{array}{c}\text { Jumlah } \\
\text { Populasi }\end{array}$ \\
\hline Kab. Lumajang & 402 & 126 & 198165 & 1028103 \\
\hline Kab. Ngawi & 374 & 44 & 190288 & 895248 \\
\hline Kab. Sampang & 103 & 73 & 40951 & 877772 \\
\hline Kab.Magetan & 450 & 29 & 196496 & 694841 \\
\hline Kab.Malang & 121 & 50 & 477275 & 2508031 \\
\hline Kab.Pasuruan & 621 & 401 & 78300 & 4710000 \\
\hline Kab.Trenggalek & 328 & 18 & 164195 & 997000 \\
\hline Kab. Kediri & 636 & 215 & 357655 & 1498916 \\
\hline Kota Batu & 165 & 23 & 59200 & 209103 \\
\hline Kab. Mojokerto & 587 & 142 & 209600 & 1100807 \\
\hline Kota Probolinggo & 145 & 14 & 199730 & 220186 \\
\hline Kab. Sidoarjo & 539 & 172 & 636000 & 1984057 \\
\hline Kab. Tulung Agung & 741 & 41 & 399840 & 1083273 \\
\hline
\end{tabular}

\section{PENGOLAHAN DAN ANALISIS DATA}

Dalam mengolah dan menganalisis data kecelakaan lalu lintas jalan pada suatu daerah, terdapat beberapa parameter pembanding guna mengidentifikasi kondisi keselamatan lalu lintas jalan tersebut, parameter-parameter yang dimaksud antara lain:

1. Jumlah kejadian kecelakaan

2. Tingkat kecelakaan

3. Tingkat fatalitas (CFR)

4. Indeks Fatalitas by kendaraan bermotor

5. Indeks Fatalitas by populasi

Berdasarkan data kecelakaan tahun 2010 dan 2011, maka dapat dilakukan analisis terhadap kelima parameter tersebut diatas sebagai berikut:

\subsection{Jumlah Kejadian Kecelakaan}

Jumlah kejadian kecelakaan tiap kota/kab di Provinsi Jawa Timur berdasarkan

Tabel 2a dan Tabel 2b dapat digambarkan secara grafik seperti terlihat pada Gambar 2a dan Gambar 2b. 


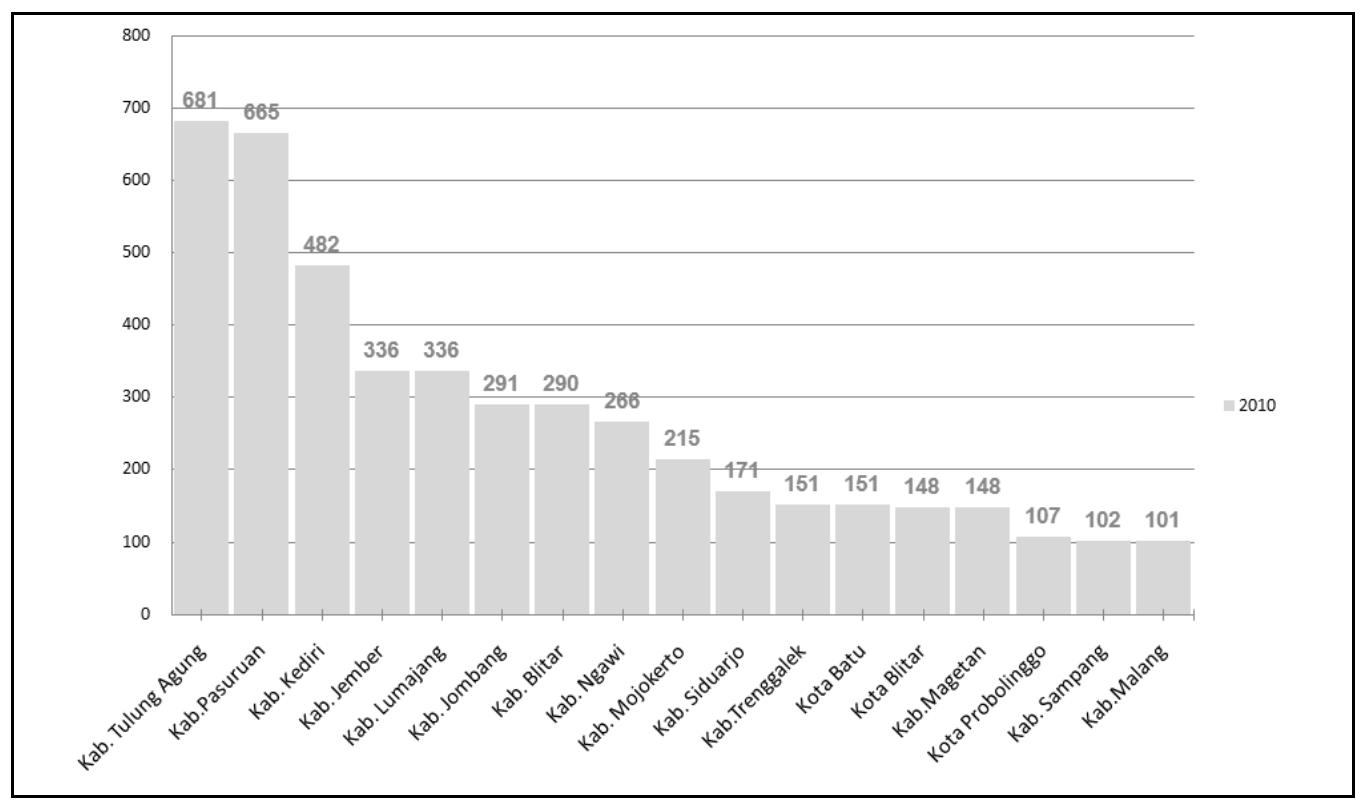

Gambar 2a. Jumlah Kejadian Kecelakaan (2010)

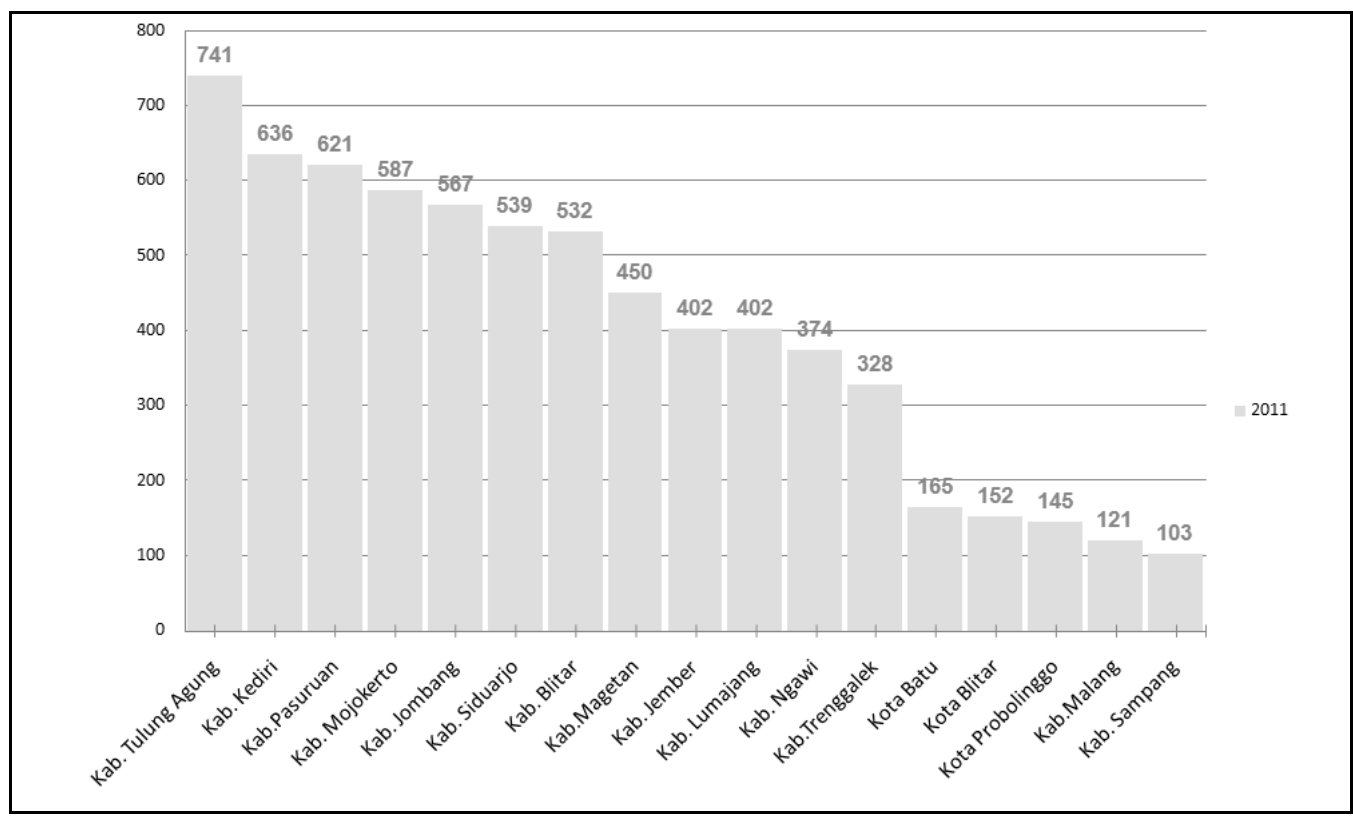

Gambar 2b. Jumlah Kejadian Kecelakaan (2011)

Dari Gambar 2a dan Gambar 2b terlihat bahwa jumlah kejadian kecelakaan tertinggi tahun 2010 dan 2011 terjadi di Kab. Tulung Agung dengan jumlah 681 kejadian (tahun 2010) dan 741 (tahun 2011). 


\subsection{Tingkat Kecelakaan}

Dengan membandingkan data jumlah kejadian kecelakaan dengan jumlah kendaraan bermotor tiap kota/kab, maka dapat diketahui tingkat kecelakaannya dan bentuk grafiknya, seperti terlihat pada Gambar 3a dan Gambar 3b.

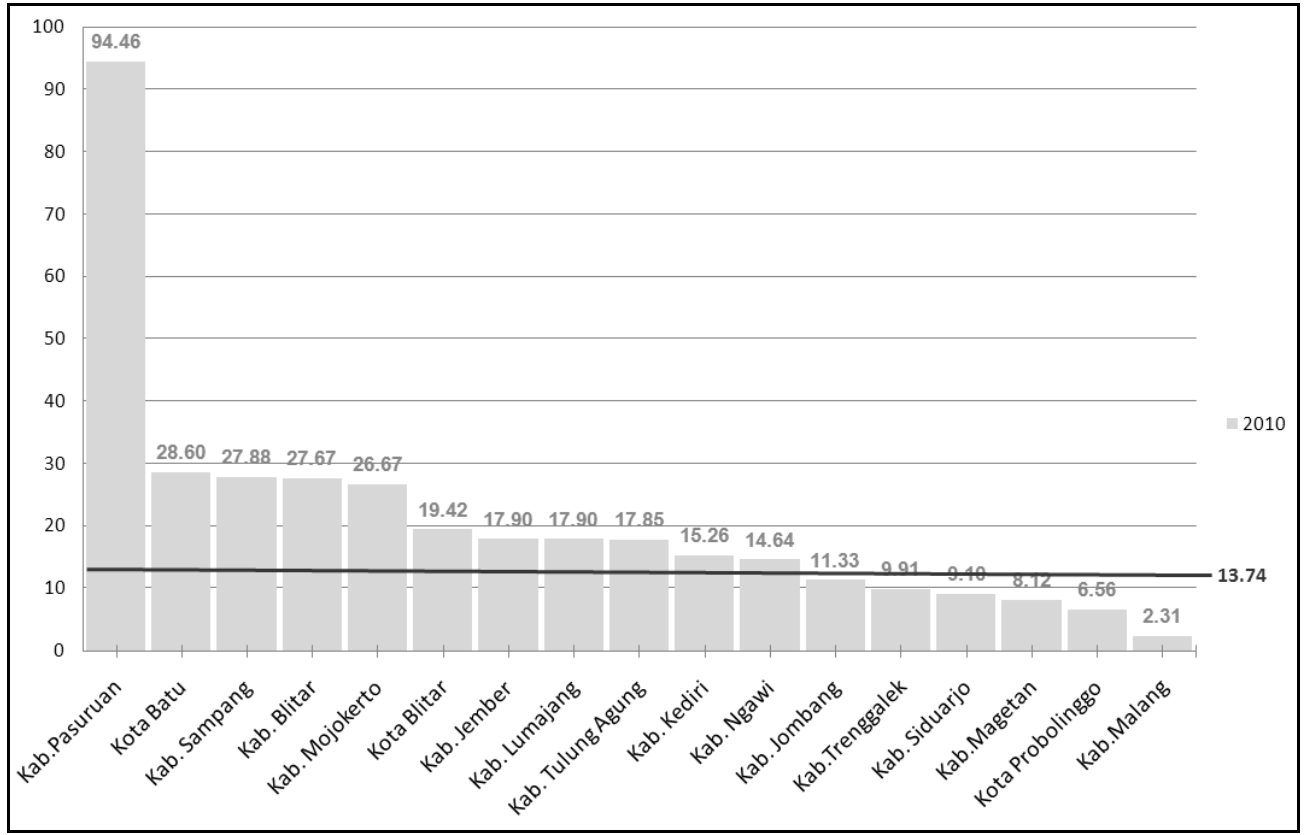

Gambar 3a. Tingkat Kecelakaan/10000 Ranmor (2010)

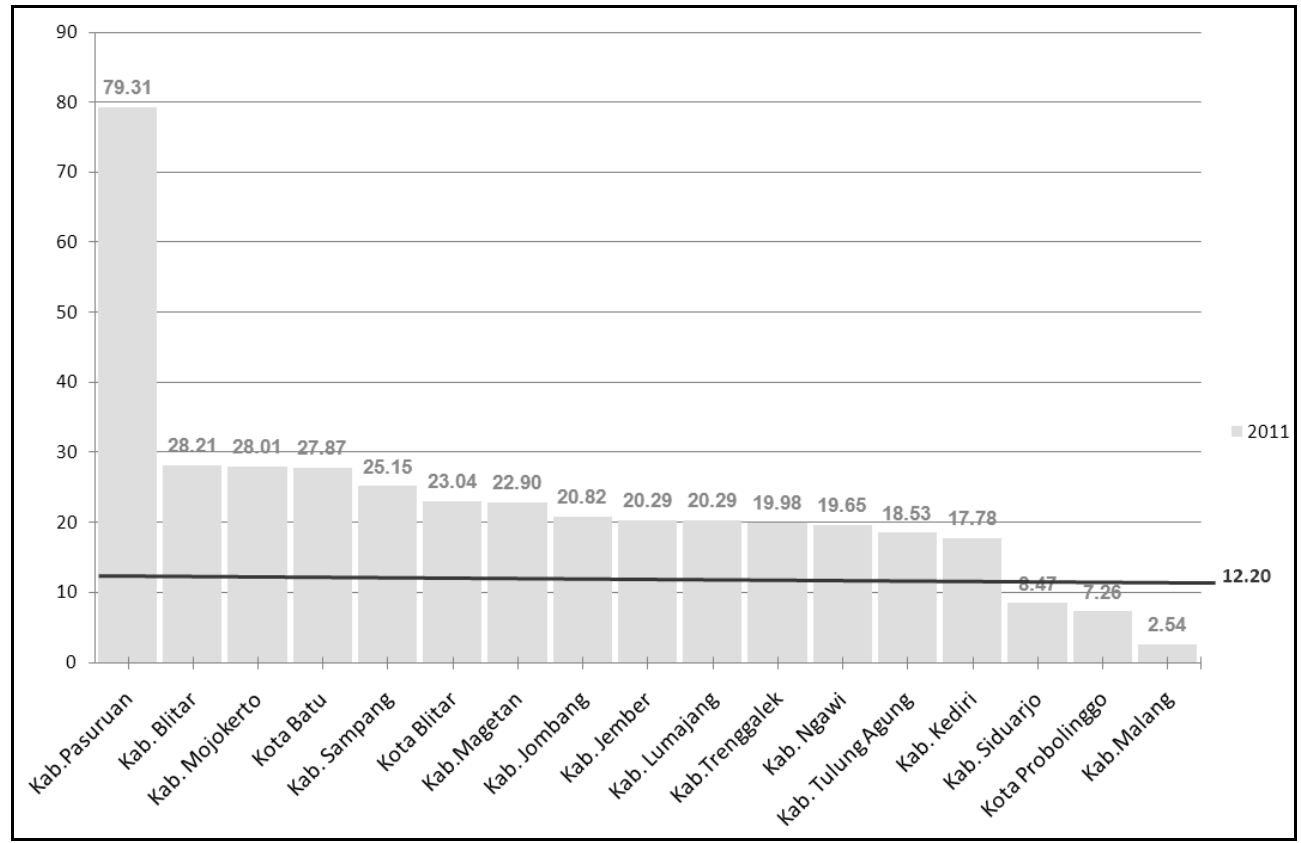

Gambar 3b. Tingkat Kecelakaan/10000 Ranmor (2011) 
Berdasarkan Gambar 3a dan Gambar 3b, terlihat tingkat kecelakaan tertinggi pada tahun 2010 dan tahun 2011 terjadi di Kab. Pasuruan, dengan angka tingkat kecelakaan sebesar 94.46 (tahun 2010) dan 79,31 (tahun 2011) kendaraan/10000 ranmor. Dengan demikian terlihat bahwa di Kab. Pasuruan telah mengalami penurunan dari segi tingkat kecelakaan.

Bila dibandingkan dengan tingkat kecelakaan secara nasional tahun 2010 yang bernilai 13.74 tingkat kecelakaan/10000 ranmor, terdapat $11 \mathrm{kab} / \mathrm{kota}$ yang berada di atas garis batas tingkat kecelakaan nasional. Sedangkan pada tahun 2011, terdapat 14 kab/kota yang berada di atas garis batas tingkat kecelakaan nasional (12.20). Hal ini menunjukkan bahwa tingkat kecelakaan/10000 ranmor di Jawa Timur semakin parah.

\subsection{Tingkat Fatalitas (CFR)}

Tingkat fatalitas (Case Fatality Rate/CFR) adalah perbandingan antara jumlah korban meninggal dunia terhadap jumlah kejadian kecelakaan. Nilai CFR pada setiap kota/kab yang ada di Provinsi Jawa Timur pada tahun 2010 dan tahun 2011 dapat dilihat pada Gambar 4a dan Gambar 4b.

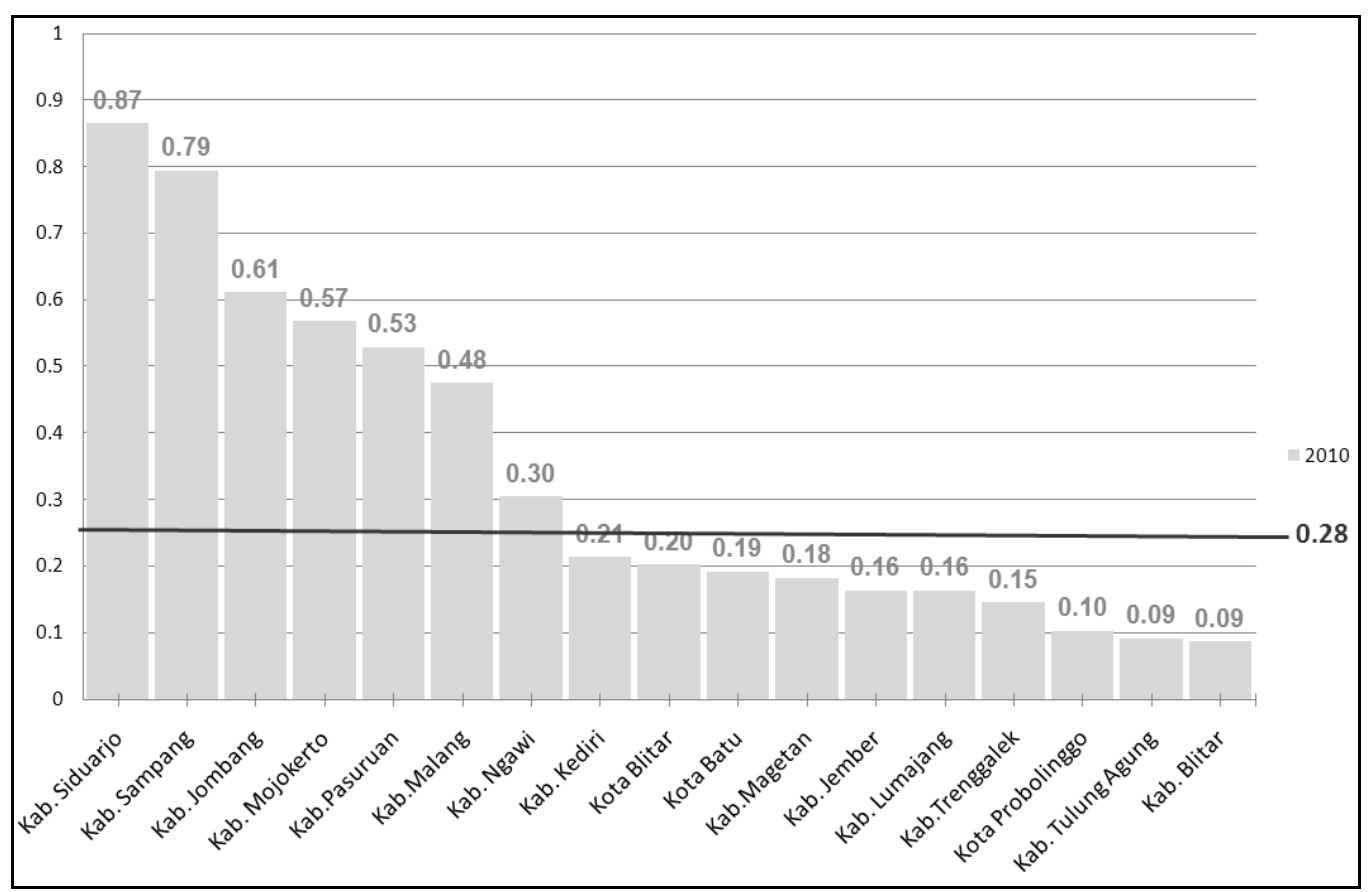

Gambar 4a. Tingkat Fatalitas (CFR) (2010)

Target Pencapaian Rencana Umum Keselamatan Jalan (Runk Jalan) di Provinsi Jawa Timur pada Tahun 2012 (Budi Hartanto Susilo) 


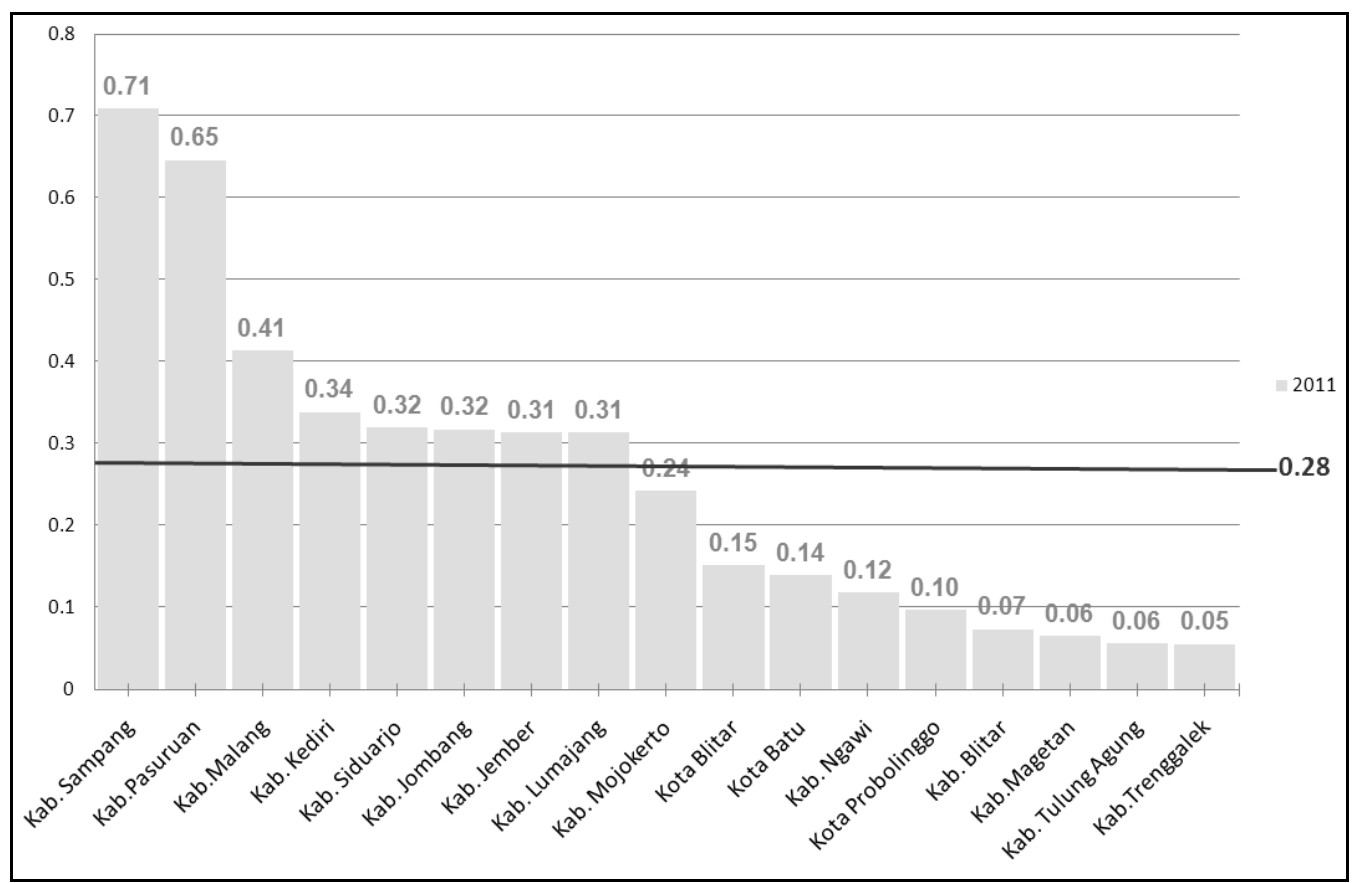

Gambar 4b. Tingkat Fatalitas (CFR) (2011)

Pada Gambar 4a dan Gambar 4b terlihat bahwa CFR tertinggi pada tahun 2010 terjadi di Kab. Sidoarjo, dengan CFR sebesar 0,87. Sedangkan pada tahun 2011, CFR tertinggi terjadi di kab. Sampang, dengan CFR sebesar 0,71.

\subsection{Indeks Fatalitas by Ranmor}

Indeks fatalitas by ranmor merupakan perbandingan antara jumlah korban meninggal dunia terhadap jumlah kendaraan bermotor (ranmor). Secara nasional, nilai indeks fatalitas by ranmor pada tahun 2010 adalah 3.93 dan pada tahun 2011 adalah 3.14. Sedangkan nilai indeks fatalitas by ranmor di setiap kota/kab di Jawa Timur pada tahun 2010 dan 2011 dapat dilihat pada Gambar 5a dan Gambar 5b. 


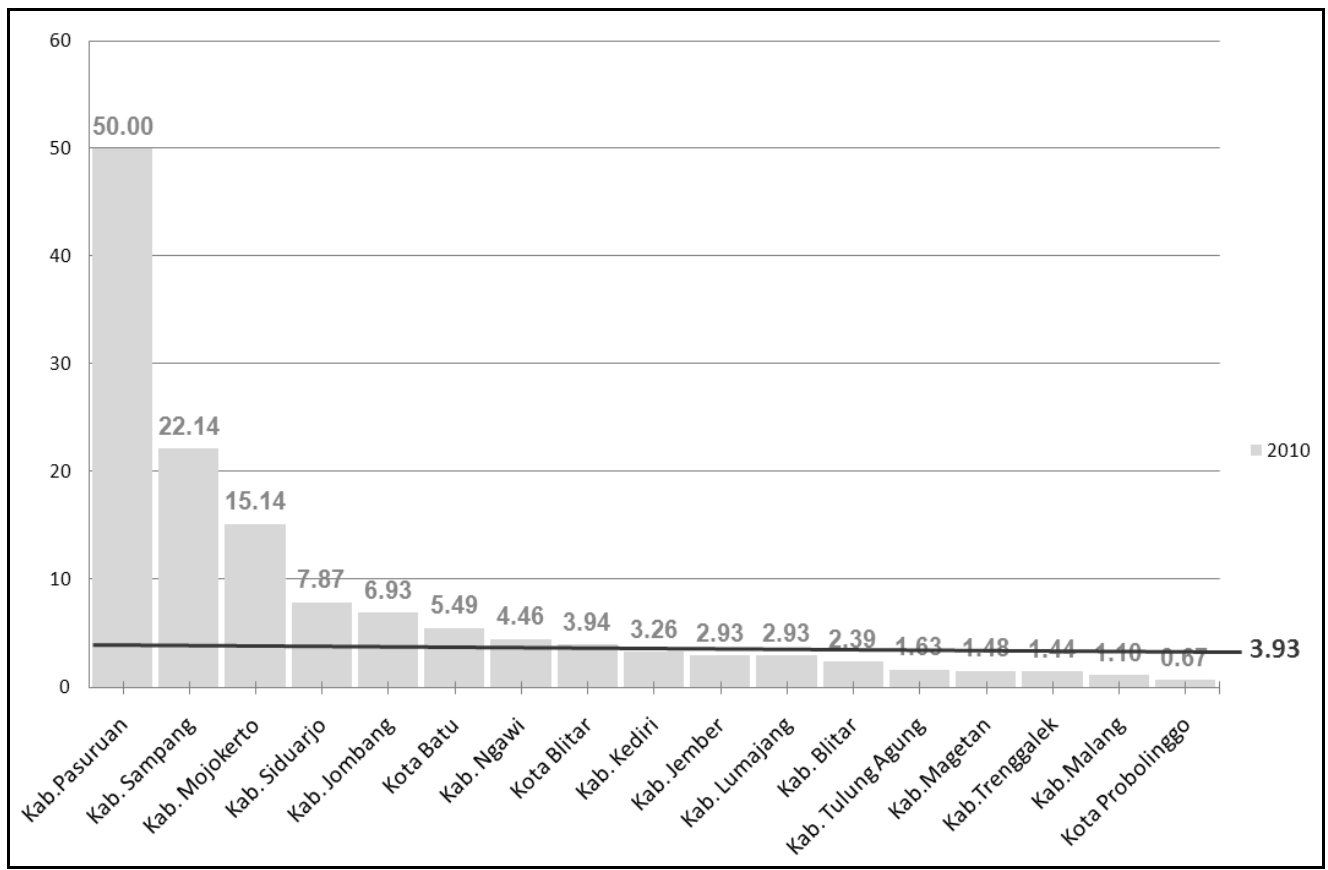

Gambar 5a. Indeks Fatalitas By Ranmor/10000 Ranmor (2010)

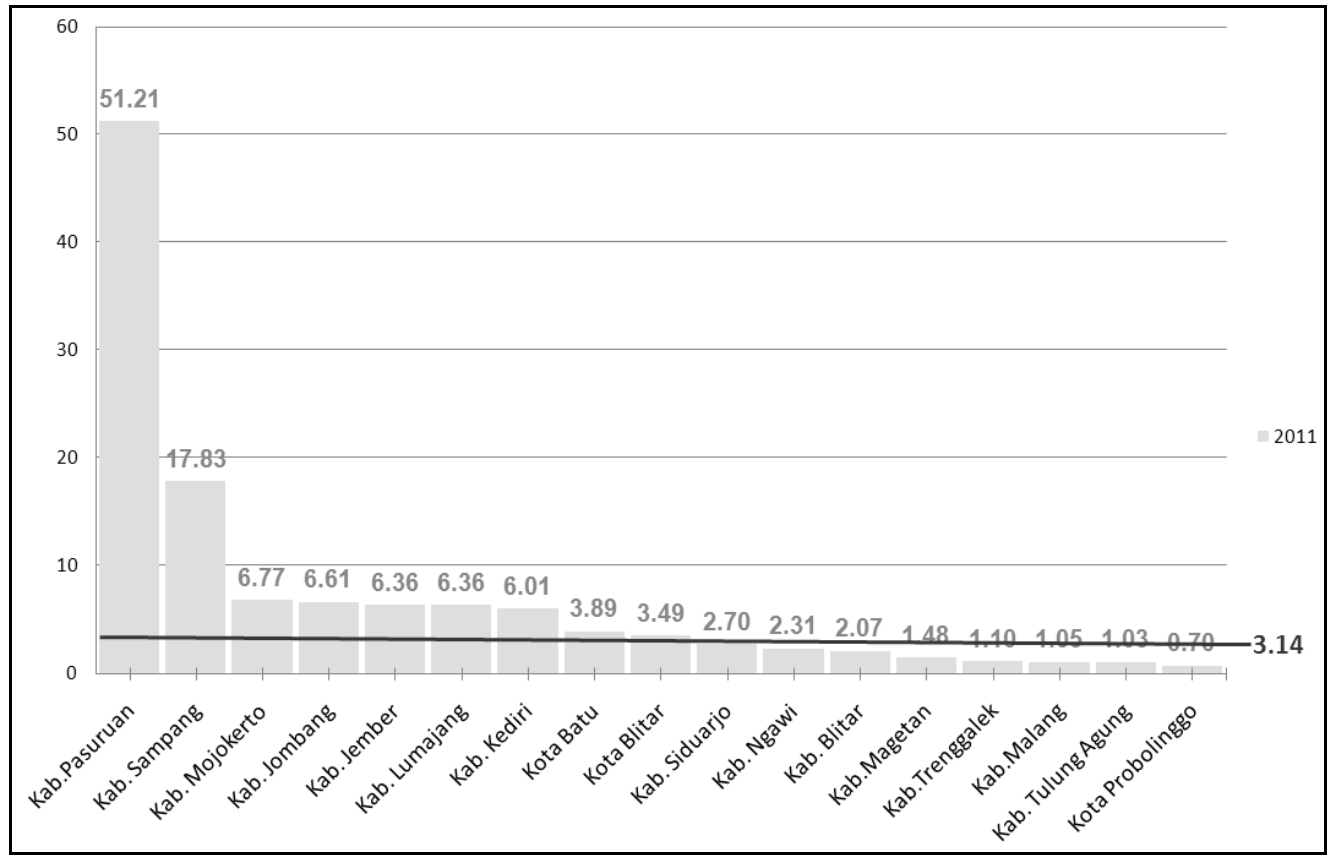

Gambar 5b. Indeks Fatalitas By Ranmor/10000 Ranmor (2011)

Berdasarkan Gambar 5a dan Gambar 5b terlihat bahwa indeks fatalitas by ranmor tertinggi terjadi di Kab. Pasuruan, dengan angka indeks sebesar 50,00. 


\subsection{Indeks fatalitas by populasi}

Indeks fatalitas by populasi merupakan perbandingan dari jumlah korban meninggal dunia akibat kecelakaan terhadap jumlah populasi di suatu daerah. Indeks fatalitas by populasi secara nasional per 100000 penduduk pada tahun 2010 adalah 13.15 dan pada tahun 2011 adalah 12.93. Sedangkan indeks fatalitas by populasi di setiap kota/kab di Jawa Timur pada tahun 2010 dan 2011 dapat dilihat pada Gambar 6a dan Gambar 6b.

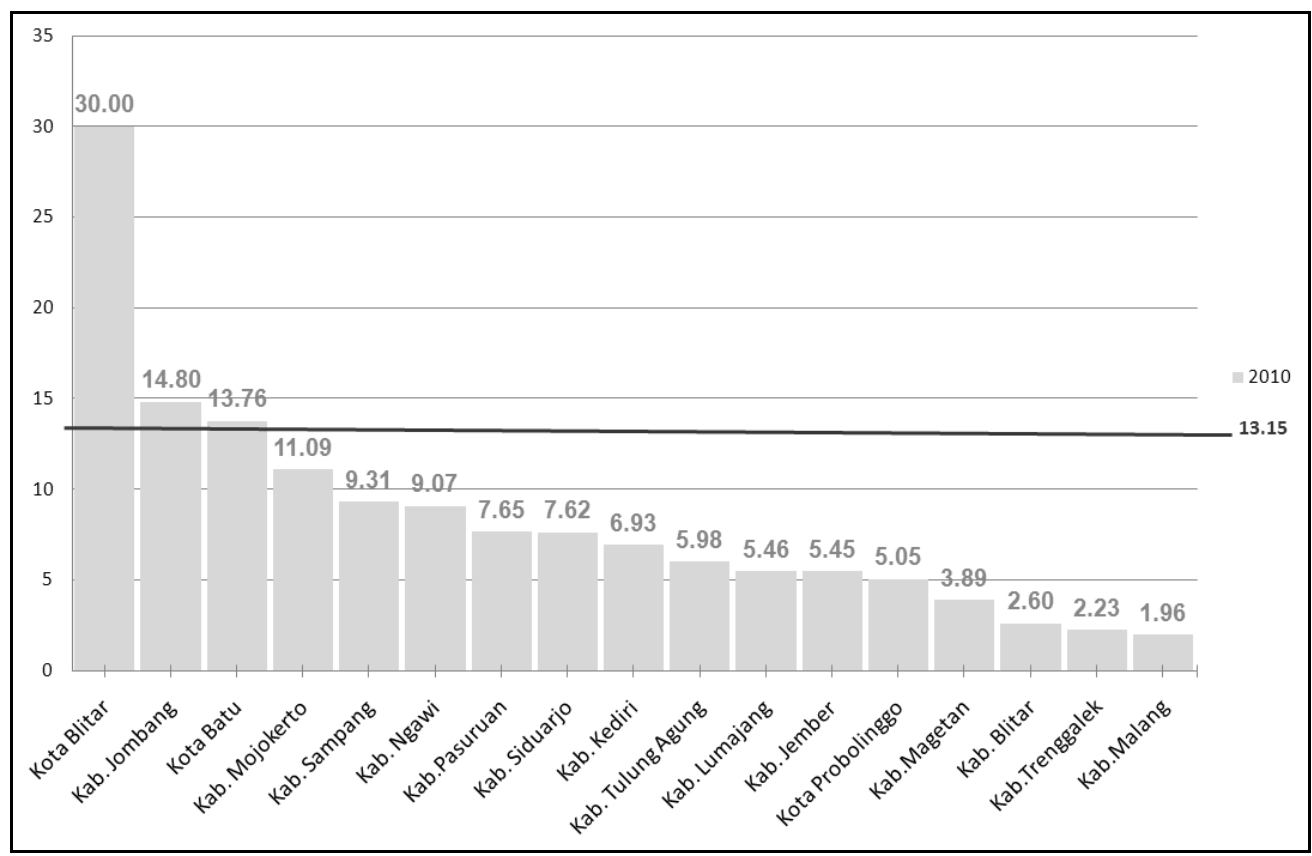

Gambar 6a. Indeks Fatalitas By Populasi/100000 Populasi (2010) 


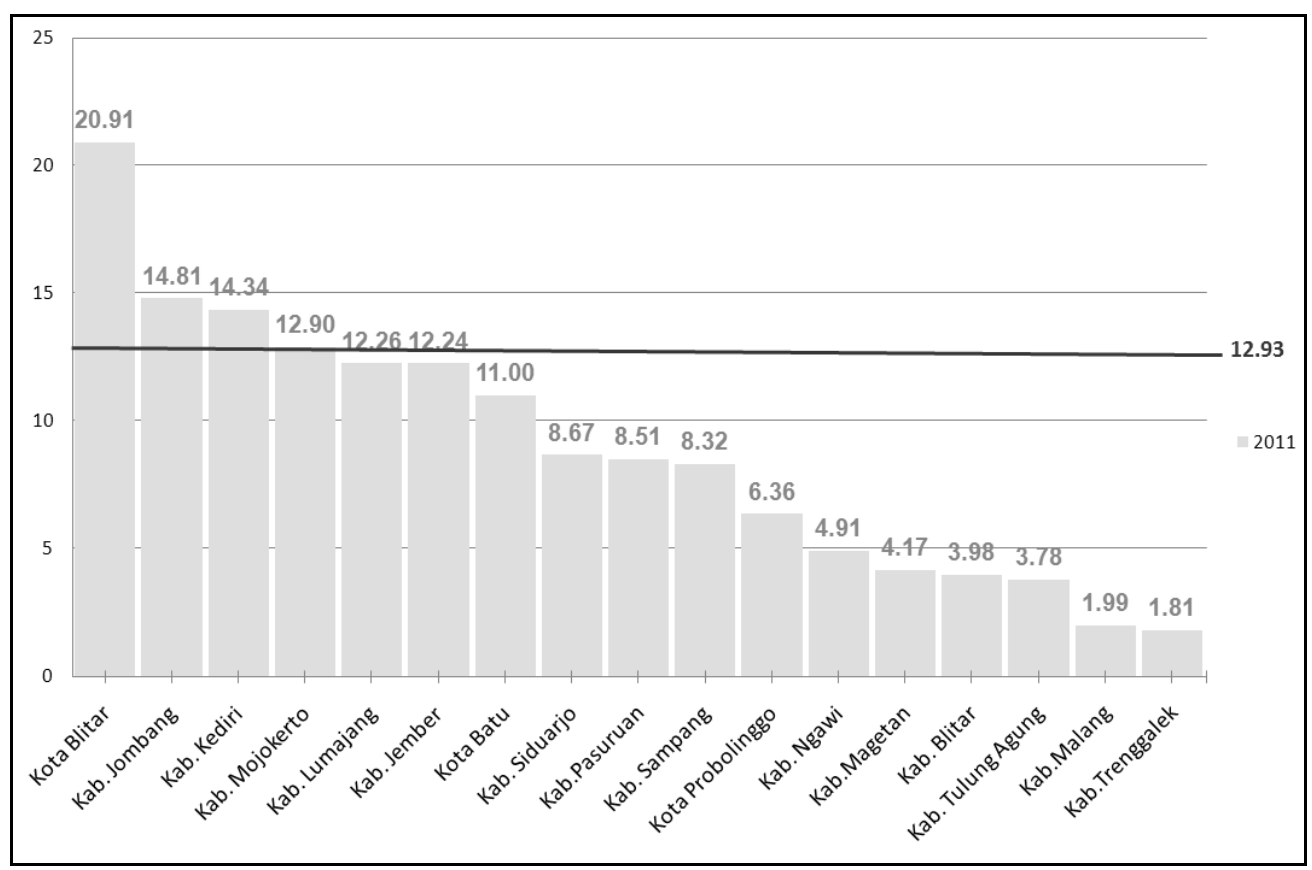

Gambar 6b. Indeks Fatalitas By Populasi/100000 Populasi (2011)

Pada Gambar 6a dan Gambar 6b terlihat bahwa indeks fatalitas by populasi tertinggi pada tahun 2010 dan 2011 terjadi di Kota Blitar, dengan nilai indeks sebesar 30.00 (tahun 2010) dan 20.91 (tahun 2011). Hal ini menunjukkan bahwa terjadi penurunan secara indeks fatalitas by populasi di Kota Blitar. Meskipun demikian, angka tersebut masih jauh di atas skala nasional $(12,93)$.

\section{KESIMPULAN}

Berdasarkan hasil pengolahan dan analisis data, maka dapat disimpulkan bahwa:

1. Jumlah kejadian kecelakaan tertinggi pada tahun 2010 dan 2011 adalah terjadi di Kab. Tulung Agung, dengan jumlah 681 kejadian (tahun 2010) dan 741 (tahun 2011).

2. Dari segi tingkat kecelakaan (jumlah kecelakaan/10000 kendaraan), bila dibandingkan dengan tingkat kecelakaan secara nasional tahun 2010 yang bernilai 13.74, terdapat $11 \mathrm{kab} / \mathrm{kota}$ yang berada di atas garis batas tingkat kecelakaan nasional. Sedangkan pada tahun 2011 (bernilai 12.20), terdapat 14 kab/kota yang berada di atas garis batas tingkat kecelakaan nasional. Hal ini menunjukkan bahwa tingkat kecelakaan/10000 ranmor di Jawa Timur semakin parah. Dengan kata lain, semakin menjauh dari target RUNK. 
3. Dari segi tingkat fatalitas (CFR), pada tahun 2010 terdapat 7 kab/kota yang berada di atas skala nasional, sedangkan pada tahun 2011 terdapat 8 kab/kota.

4. Dari segi indeks fatalitas by kendaraan bermotor, pada tahun 2010 terdapat 8 kab/kota yang berada di atas skala nasional, sedangkan pada tahun 2011 terdapat 9 kab/kota.

5. Dari segi indeks fatalitas by populasi, pada tahun 2010 dan 2011 terdapat 3 kab/kota yang berada di atas skala nasional.

Secara keseluruhan, bahwa terjadi peningkatan baik dari segi jumlah maupun tingkat kecelakaan dari tahun 2010 sampai 2011. Hal ini menunjukkan bahwa kesadaran akan keselamatan jalan di Jawa Timur masih belum membaik secara signifikan. Dengan kata lain target RUNK belum tercapai.

\section{DAFTAR PUSTAKA}

1. KORLANTAS POLRI, (2011). Jumlah Korban Meninggal Dunia Akibat Kecelakaan Lalu Lintas Tahun 2010.

2. Pemerintah Republik Indonesia, (2011). Rencana Umum Nasional Keselamatan (RUNK) Jalan 2011 - 2035.

3. Resolusi PBB No. 64/255, Decade of Action (DoA), 2011-2020.

4. Susilo, B.H., (2012). Analisis Data Kecelakaan dan Simulasi Penanganan LRK, Kegiatan Peningkatan Kapasitas dalam Bidang Keselamatan, Tema: “Menuju Kualitas SDM Bidang Keselamatan LLAJ yang Profesional”, Palembang.

5. Undang-Undang Republik Indonesia (2009), No. 22 Tentang Lalu Lintas dan Angkutan Jalan. 